\title{
In vitro Effects of New Generation Oxazaphosphorines on Human Promyelocytic Leukemia Cells*
}

\author{
Lidia MAZUR, Małgorzata OPYDO-CHANEK, Marta STOJAK and Ulf NIEMEYER
}

Accepted November 22, 2012

\begin{abstract}
Mazur L., Opydo-Chanek M., Stojak M., Niemeyer U. 2013. In vitro effects of new generation oxazaphosphorines on human promyelocytic leukemia cells Folia Biologica (Kraków) 61: 31-40.

Mafosfamide cyclohexylamine salt (D-17272), 4-hydro-peroxy-cyclophosphamide (D-18864) and glufosfamide (D-19575, $\beta$-D-glucose-isophosphoramide mustard) are new generation oxazaphosphorine agents. The present investigation was undertaken to determine the activity of these three oxazaphosphorines in human promyelocytic leukemia HL-60 cells. The research was conducted using the spectrophotometric MTT assay and the electronic Beckman Coulter and microscopy methods. Functional and morphological changes were observed after exposure of HL-60 cells to the oxazaphosphorine agents. The various patterns of temporary alterations in cell viability, size and count, and also in the frequency of leukemic cells undergoing mitotic catastrophe, apoptosis and necrosis, were shown. Different leukemic cell responses to the action of the three oxazaphosphorines were evaluated. These are the first data comparing the in vitro activity of D-17272, D-18864 and D-19575 against human promyelocytic leukemia cells.
\end{abstract}

Key words: oxazaphosphorines, cell viability, volume and count, mitotic catastrophe, apoptosis, necrosis.

Lidia MAZUR, Matgorzata OPYDO-CHANEK, Marta STOJAK, Department of Experimental Hematology, Jagiellonian University, Gronostajowa 9, 30-387 Kraków, Poland.

E-mail:lidia.mazur@uj.edu.pl malgorzata.opydo-chanek@uj.edu.pl marta.stojak@uj.edu.pl

Ulf NIEMEYER, NIOMECH part of IIT GmbH, University of Bielefeld, Universitätsstr. 25,

33615 Bielefeld, Germany.

E-mail: ulf_niemeyer@t-online.de

Oxazaphosphorines represent an important class of anticancer alkylating agents. Cyclophosphamide, ifosfamide and trofosfamide are commonly used in the treatment of a wide variety of solid tumors and hematological malignancies. New generation oxazaphosphorine agents have been developed in an attempt to improve the efficacy of chemotherapy. Mafosfamide cyclohexylamine salt, 4-hydro-peroxy-cyclophosphamide and glufosfamide (Fig. 1) are new oxazaphosphorines. An assessment of the activity of these alkylating agents against pathological cells is of key importance in chemotherapy (STYCZYŃSKI et al. 2002a; ZHANG et al. 2005a; LIANG et al. 2007; JACOB et al. 2008; GIRAUD et al. 2010; MAZUR et al. 2011, 2012a).

Cell viability, mitotic catastrophe, cell death, and cell size and count are accepted important parameters for determining and characterizing the anticancer activity of various chemotherapeutic agents (ROSS 1976, 1981a, 1981b; KASPERS et al. 1995; MAKIN \& HICKMAN 2000; BECKER et al. 2002; BORST \& ROTTENBERG 2004; MANSILLA et al. 2006; RICCI \& ZONG 2006; DE BRUIN \& Medema 2008; Sun \& PENG 2009). Nevertheless, available information on the antileukemic potential of the new oxazaphosphorines is scarce. The in vitro activity of mafosfamide cyclohexylamine salt, glufosfamide, and 4-hydroperoxy-cyclophosphamide has only been studied in childhood acute leukemia cells, human lymphoblastoid cells, human histiocytic lymphoma U937 cells, human acute lymphoblastic leukemia MOLT-4 cells, and human acute myeloblastic leukemia ML-1 cells (STYCZYŃSKI et al. 2006b; GOLDSTEIN et al. 2008; MAZUR et al. 2009, 2010, 2012b; OPYDO-CHANEK et al. 2010, 2011). 


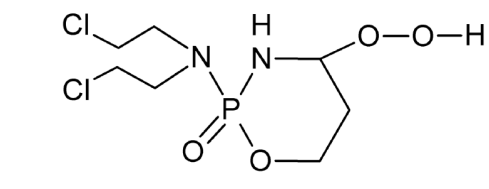

4-Hydroperoxycyclofosfamide (D-18864)

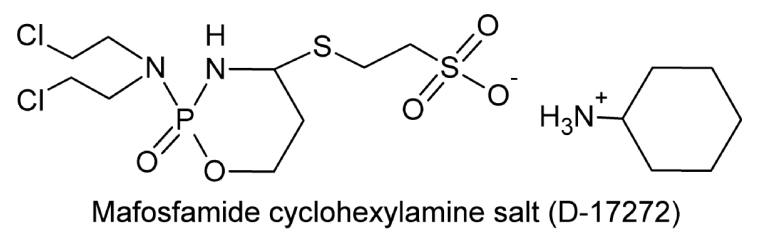<smiles>O=P(NCCCl)(NCCCl)O[C@@H]1O[C@H](CO)[C@@H](O)[C@H](O)[C@H]1O</smiles>

Fig. 1. The chemical structures of the three oxazaphosphorine agents D-18864, D-17272, and D-19575.

The leukemic cell response to the action of the new oxazaphosphorines has not yet been completely explained and is still under investigation.

The aim of the present investigation was to evaluate and compare the in vitro activities of mafosfamide cyclohexylamine salt, 4-hydro-peroxycyclophosphamide and glufosfamide, against human promyelocytic leukemia HL-60 cells. After oxazaphosphorine application, temporary changes in leukemic cell viability, size and count and also in the frequency of HL-60 cells undergoing mitotic catastrophe, i.e. the process preceding cell death (MANSILLA et al. 2006), and two major types of programmed death, apoptosis and necrosis (KAUFMANN \& EARNSHAW 2000; MAKIN \& HICKMAN 2000; BORST \& ROTTENBERG 2004; HENDRIQUEZ et al. 2008; SUN \& PENG 2009), were analyzed.

\section{Material and Methods}

\section{Cells}

Human promyelocytic leukemia HL-60 cells (American Type Culture Collection, Rockville, MD, USA) were maintained in RPMI 1640 medium (Gibco BRL Life Technologies), supplemented with $10 \%$ fetal calf serum (GIBCO BRL Life Technologies), $2 \mathrm{mM}$ L-glutamine (Sigma Aldrich), and antibiotic antimycotic solution (AAS, Sigma Aldrich). AAS contained 20 units of penicillin, $20 \mu \mathrm{g}$ streptomycin and $0.05 \mu \mathrm{g}$ amphotericin B. Every third day, HL-60 cells were passaged. The cells grew at $37^{\circ} \mathrm{C}$ in an atmosphere of $5 \% \mathrm{CO}_{2}$ in air (HERAcell incubator, KendroLab).

\section{Chemicals}

Mafosfamide cyclohexylamine salt (D-17272), 4-hydro-peroxy-cyclophosphamide (D-18864) and glufosfamide (D-19575, $\beta$-D-glucose-isophosphoramide mustard) were obtained from NIOMECH (Bielefeld, Germany). D-17272, D-18864 and D-19575 were dissolved in aqua pro injectione (Polpharma). All solutions were freshly prepared directly before treatment of the leukemic HL-60 cells.

\section{Oxazaphosphorine doses and cell treatment}

After a dilution of the cell suspension to a density of $15 \times 10^{4}$ cells $/ \mathrm{ml}$ medium, HL-60 cells were subjected to a 60 min oxazaphosphorine agent exposure. D-18864 was given at a dose of $10 \mu \mathrm{g} / \mathrm{ml}$ medium, D-19575 at a dose of $100 \mu \mathrm{g} / \mathrm{ml}$ medium, and D-17272 was applied in two doses: $10 \mu \mathrm{g} / \mathrm{ml}$ and $100 \mu \mathrm{g} / \mathrm{ml}$ medium. The control material consisted of untreated HL-60 cells. After a $60 \mathrm{~min}$ treatment with the oxazaphosphorine agent, leukemic cells were centrifuged at $1000 \mathrm{rpm}$ (MPW-360R centrifuge, Med. Instruments) for $10 \mathrm{~min}$, and the supernatant was discarded. The cells were then washed in $2 \mathrm{ml}$ of PBS (BioMed) and pelletted by centrifugation for $7 \mathrm{~min}$. The wash and centrifugation were repeated once more and the cells were resuspended in the complete RPMI 1640 medium.

\section{Analyses of HL-60 cells after oxazaphosphorine} application

Temporary changes occurring in human promyelocytic leukemia HL-60 cells were determined at 24, 48, and $72 \mathrm{~h}$ after cell exposure to the oxazaphosphosphorine agent. At these three time intervals, the cell viability, volume and count, and also the frequency of cells undergoing mitotic catastrophe, apoptosis and necrosis, were analyzed. 


\section{In vitro spectrophotometric MTT assay}

In viable, metabolically active cells, the tetrazolium ring of MTT (3-[4,5-dimethylthiazol-2yl]-2,5-diphenyl tetrazolium bromide) is cleaved, yielding formazan crystals. Changes in the metabolic activity of cell populations result in a concomitant change in the amount of formazan formed.

MTT (Sigma-Aldrich) was dissolved in RPMI 1640 medium, at a concentration of $5 \mathrm{mg} / \mathrm{ml}$, and filtered through a $0.2 \mu \mathrm{m}$ filter. $100 \mu \mathrm{l}$ of the yellow MTT solution was added to each well of a 24-well plate, containing $1 \mathrm{ml}$ of the cell suspension, and the cells were incubated at $37^{\circ} \mathrm{C}$ with $5 \% \mathrm{CO}_{2}$. The blank solution was prepared according to the above procedure using complete medium without cells. After the three-hour incubation period, the resulting formazan crystals were dissolved with $1 \mathrm{ml}$ of acidified isopropanol $(0.05 \mathrm{~N} \mathrm{HCl}$ in absolute isopropanol). Absorbance of the obtained solution was measured at a wavelength of $570 \mathrm{~nm}$ using a Pharmacia Ultrospec III spectrophotometer (Pharmacia). The extent of MTT conversion in cells was also expressed as a percentage value of the control.

\section{Measurement of HL-60 cell size and count}

The Beckman Coulter method of cell sizing and counting is based on the detection of an electrical pulse which results from the passage of each cell through an aperture. The amplitude of the produced electrical pulse depends on the cell volume. The number of pulses indicates the cell count.

Samples of HL-60 cell suspension were taken from flasks and immediately diluted in ISOTON II (Beckman Coulter filtered electrolyte solution based on $0.9 \%$ saline). $500 \mu 1$ of the cell suspension was added to $4.5 \mathrm{ml}$ of ISOTON II. After the dilution of the leukemic cell suspension, individual HL-60 cells were measured using a Z2 Coulter counter (Beckman Coulter, USA). The volume and count distribution of HL-60 cells was obtained using a counter equipped with a $100 \mu \mathrm{m}$ diameter orifice. The flow rate was $500 \mu \mathrm{l} / 12.5 \mathrm{sec}$. The range for cell measurement was determined as 268-7346 fL. The cell volume and count was analyzed at 832-7346 fL. The instrument was calibrated using $10 \mu$ m diameter latex beads (Beckman Coulter $\mathrm{CC}$ size standard). The mean cell volume and the cell count were determined using Z2 AccuComp software (Beckman Coulter, USA).

\section{Microscopy analysis of HL-60 cells}

HL-60 cell suspension, eventually diluted in HBBS (GIBCO BRL Life Technologies), containing approximately $2 \times 10^{5}$ cells, was added into a cytospin chamber and centrifuged at $1000 \mathrm{rpm}$ (MPW-350R centrifuge, Med. Instruments) for $6 \mathrm{~min}$, at $4^{\circ} \mathrm{C}$. After air drying, the prepared cytospins were fixed in a mixture of ethanol and acetic acid solution (9:1), at room temperature for $30 \mathrm{~min}$. Immediately before staining, the slides with the fixed cells were rinsed with PBS (BioMed). The cytospins were stained with a dye solution containing $1 \mu \mathrm{g} / \mathrm{ml}$ of 4'-6'-diamino-2-phenylindole (DAPI) and sulforhodamine 101 (Sigma Aldrich), for 3-5 min. The slides were then rinsed in PBS and the cytospins were mounted under a coverslip in a drop of PBS.

Three cytospins from each experimental group, stained with DAPI and sulforhodamine 101, were examined under 400x magnification, using a Jenaval epifluorescent microscope (Carl Zeiss, Germany). Based on the morphology of leukemic cells, the frequency of HL-60 cells undergoing mitotic catastrophe, apoptosis, and necrosis was calculated. The incidence of cells with mitotic catastrophe, apoptotic and necrotic cells among 9000 HL-60 cells (3000 cells per slide) was determined.

The cells undergoing mitotic catastrophe express multiple mitotic abnormalities, such as missegregation and condensation of chromosomes, and chromosome alignment defects. Mitotic catastrophe is also characterized by the formation of multinucleated giant cells with uncondensed abnormal nuclei, and also micronuclei (MANSILLA et al. 2006; RICCI \& ZONG 2006). The features of apoptosis include cell shrinkage, chromatin condensation, nuclear fragmentation, and cell disassembly into apoptotic bodies. Characteristic features of necrosis are cell swelling, complete morphological cell disintegration, membrane rupture and the release of cell content (RAFFRAY \& COHEN 1997; PROSKURYAKOV et al. 2002; RICCI \& ZONG 2006; DE BRUIN \& MEDEMA 2008). The morphological criteria described above discriminated between leukemic cells which underwent mitotic catastrophe, apoptosis, and necrosis.

\section{Statistical evaluation}

Statistical significance of differences in the amount of formazan formed, the cell volume and count, and in the frequency of cells undergoing mitotic catastrophe, apoptosis, and necrosis, were evaluated by an analysis of variance and Duncan's new multiple range test. A difference with $\mathrm{P}<0.05$ was considered statistically significant. The results were confirmed by three independent experiments carried out in triplicate. 


\section{Results}

Effects of oxazaphosphorines on HL-60 cells

We determined the influence of new generation oxazaphosphorines D-17272, D-18864 and D-19575 on human promyelocytic leukemia HL-60 cells. The effects of these three oxazaphosphorine agents on cell viability (Table 1, Fig. 2), cell size (Table 2, Fig. 3) and count (Table 3), the induction of mitotic catastrophe (Table 4, Fig. 4), the triggering of apoptosis (Table 5, Fig. 4) and necrosis (Table 6, Fig. 4) were compared.

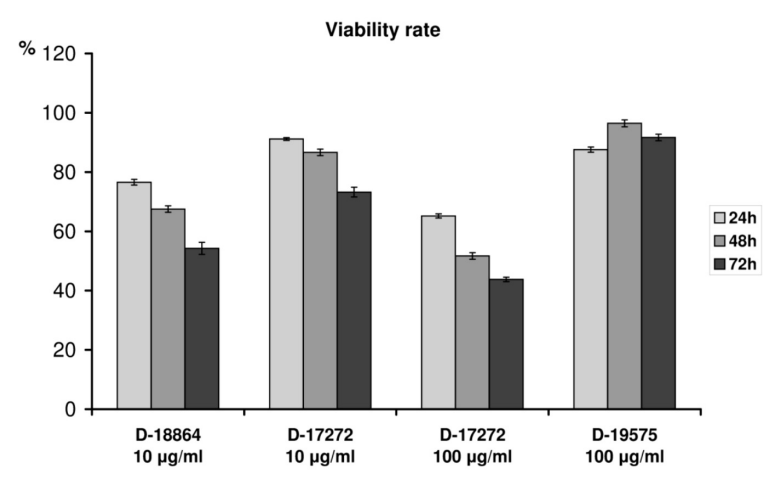

Fig. 2. Effects of oxazaphosphorines on the viability rate of HL-60 cells. The extent of MTT conversion to formazan in HL-60 cells, expressed as a percentage value of the control.

\section{Cell viability}

The leukemic cell viability was correlated with the optical density of the formazan solution. In comparison with the controls, the optical density of the formazan solution decreased $24 \mathrm{~h}, 48 \mathrm{~h}$, and $72 \mathrm{~h}$ after treatment of HL-60 cells with D-18864, $\mathrm{D}-17272$, and at $24 \mathrm{~h}$ and $72 \mathrm{~h}$ after leukemic cell exposure to the action of D-19575. Among HL-60 cells treated with the oxazaphosphorines, the smallest values of the optical density of the formed formazan were found following D-17272 application at a dose of $100 \mu \mathrm{g} / \mathrm{ml}$. The values of the optical density of the formazan solution appeared greater when D-17272 was given at a dose of $10 \mu \mathrm{g} / \mathrm{ml}$ medium, as compared with values obtained after D-18864 application at the same dose. Moreover, greater optical density of formazan was observed after treatment of HL-60 cells with D-19575 than when D-17272 was applied at the same dose of $100 \mu \mathrm{g} / \mathrm{ml}$ medium (Table 1). The viability rate, expressed as a percentage value of the control, appeared to be distinctly decreased in HL-60 cells treated with D-18864, and especially in leukemic cells exposed to the action of D-17272 at a dose of $100 \mu \mathrm{g} / \mathrm{ml}$ medium (Fig. 2).

\section{Cell size}

In relation to the controls, the mean volume of HL-60 cells increased in all the remaining experi-

Table 1

The optical density of formazan solution determined in HL-60 cells after their exposure to the oxazaphosphorine agents

\begin{tabular}{|c|c|c|c|c|c|}
\hline \multirow{2}{*}{\multicolumn{3}{|c|}{ Group characteristic }} & \multicolumn{3}{|c|}{ Time intervals after cell exposure to oxazaphosphorines } \\
\hline & & & $24 \mathrm{~h}$ & $48 \mathrm{~h}$ & $72 \mathrm{~h}$ \\
\hline \multirow{2}{*}{ No. } & \multirow{2}{*}{ Agent given } & \multirow{2}{*}{ Agent dose } & \multicolumn{3}{|c|}{ Optical density of formazan solution $\left(\times 10^{-2}\right)$} \\
\hline & & & Mean $\pm \mathrm{SD}$ & Mean \pm SD & Mean \pm SD \\
\hline I & D-18864 & $10 \mu \mathrm{g} / \mathrm{ml}$ & $\begin{array}{c}2,3,4,5,48 \mathrm{~h}, 72 \mathrm{~h} \\
16.25 \pm 0.97\end{array}$ & $\begin{array}{c}2,3,4,5,24 \mathrm{~h}, 72 \mathrm{~h} \\
26.71 \pm 1.09\end{array}$ & $\begin{array}{c}2,3,4,5,24 \mathrm{~h}, 48 \mathrm{~h} \\
31.91 \pm 2.03\end{array}$ \\
\hline II & D-17272 & $10 \mu \mathrm{g} / \mathrm{ml}$ & $\begin{array}{c}1,3,4,5,48 \mathrm{~h}, 72 \mathrm{~h} \\
19.35 \pm 0.48\end{array}$ & $\begin{array}{c}1,3,4,5,24 \mathrm{~h}, 72 \mathrm{~h} \\
34.27 \pm 1.08\end{array}$ & $\begin{array}{c}1,3,4,5,24 \mathrm{~h}, 48 \mathrm{~h} \\
43.08 \pm 1.64\end{array}$ \\
\hline III & D-17272 & $100 \mu \mathrm{g} / \mathrm{ml}$ & $\begin{array}{c}1,2,4,5,48 \mathrm{~h}, 72 \mathrm{~h} \\
13.84 \pm 0.69\end{array}$ & $\begin{array}{l}1,2,4,5,24 \mathrm{~h}, 72 \mathrm{~h} \\
20.45 \pm 1.11\end{array}$ & $\begin{array}{c}1,2,4,5,24 \mathrm{~h}, 48 \mathrm{~h} \\
25.75 \pm 0.74\end{array}$ \\
\hline IV & D-19575 & $100 \mu \mathrm{g} / \mathrm{ml}$ & $\begin{array}{c}1,2,3,5,48 \mathrm{~h}, 72 \mathrm{~h} \\
18.59 \pm 0.88\end{array}$ & $\begin{array}{c}1,2,3,24 \mathrm{~h}, 72 \mathrm{~h} \\
38.16 \pm 1.20\end{array}$ & $\begin{array}{c}1,2,3,5,24 \mathrm{~h}, 48 \mathrm{~h} \\
53.92 \pm 1.09\end{array}$ \\
\hline $\mathrm{V}$ & \multicolumn{2}{|c|}{ Control } & $\begin{array}{c}1,2,3,4,48 \mathrm{~h}, 72 \mathrm{~h} \\
21.23 \pm 1.31\end{array}$ & $\begin{array}{l}1,2,3,24 \mathrm{~h}, 72 \mathrm{~h} \\
39.57 \pm 1.15\end{array}$ & $\begin{array}{c}1,2,3,4,24 \mathrm{~h}, 48 \mathrm{~h} \\
58.82 \pm 1.32\end{array}$ \\
\hline
\end{tabular}

The data are presented as mean values \pm standard deviation.

Statistically significant differences at $\mathrm{P}<0.05$

Differences between experimental groups: different from Group I-1; Group II - 2; Group III - 3; Group IV - 4; Group V - 5.

Differences within each experimental group: different from $24 \mathrm{~h}-24 \mathrm{~h} ; 48 \mathrm{~h}-48 \mathrm{~h} ; 72 \mathrm{~h}-72 \mathrm{~h}$. 

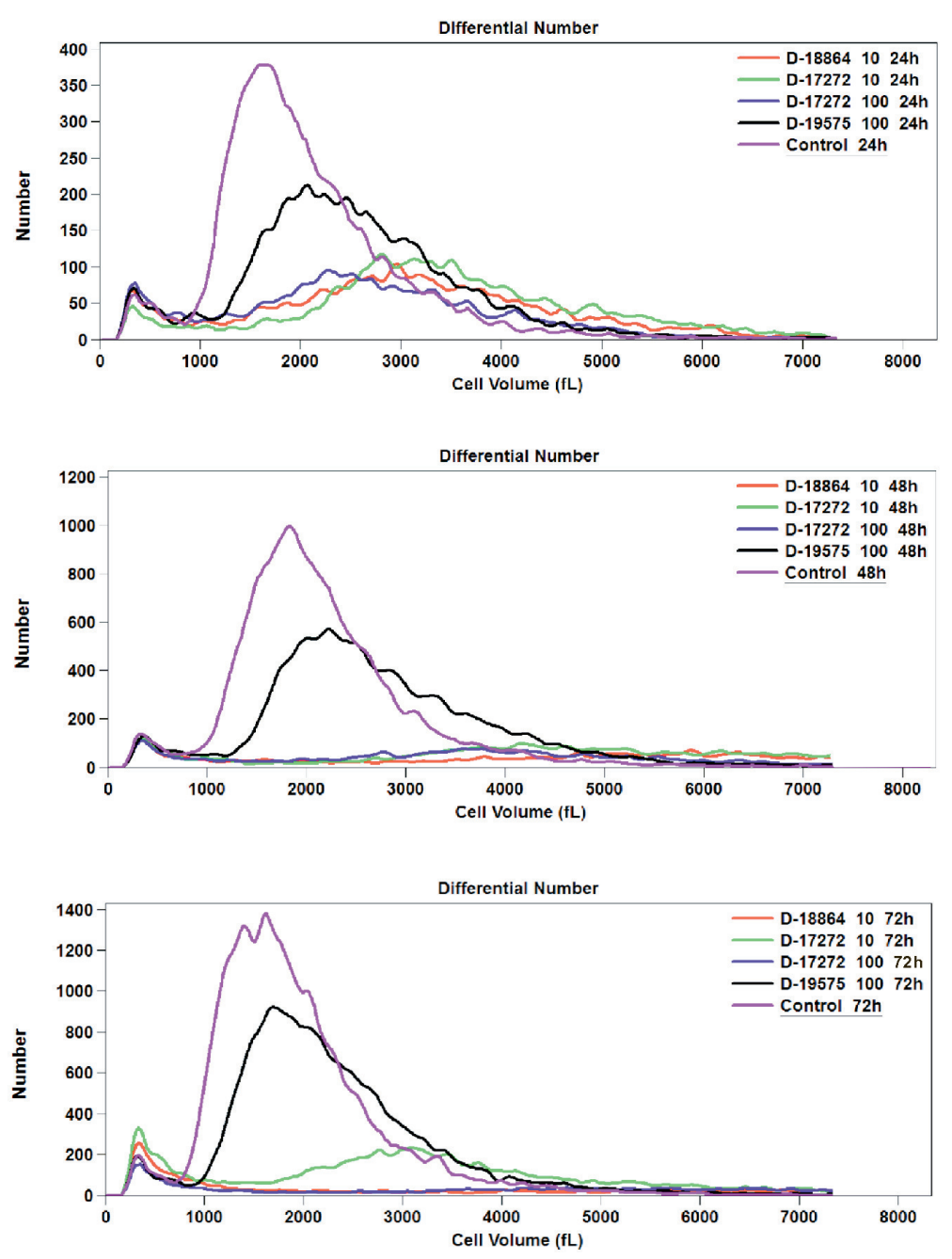

Fig. 3. The mean volume of HL-60 cells after their exposure to the action of three oxazaphosphorine agents. The peaks on the left represent cellular debris, presumably apoptotic bodies and necrotic cell fragments, which were excluded from the analysis of HL-60 cell volume. 10 - the oxazaphosphorine agent applied at a dose of $10 \mu \mathrm{g} / \mathrm{ml}$ medium; 100 - the oxazaphosphorine agent applied at a dose of $100 \mu \mathrm{g} / \mathrm{ml}$ medium.
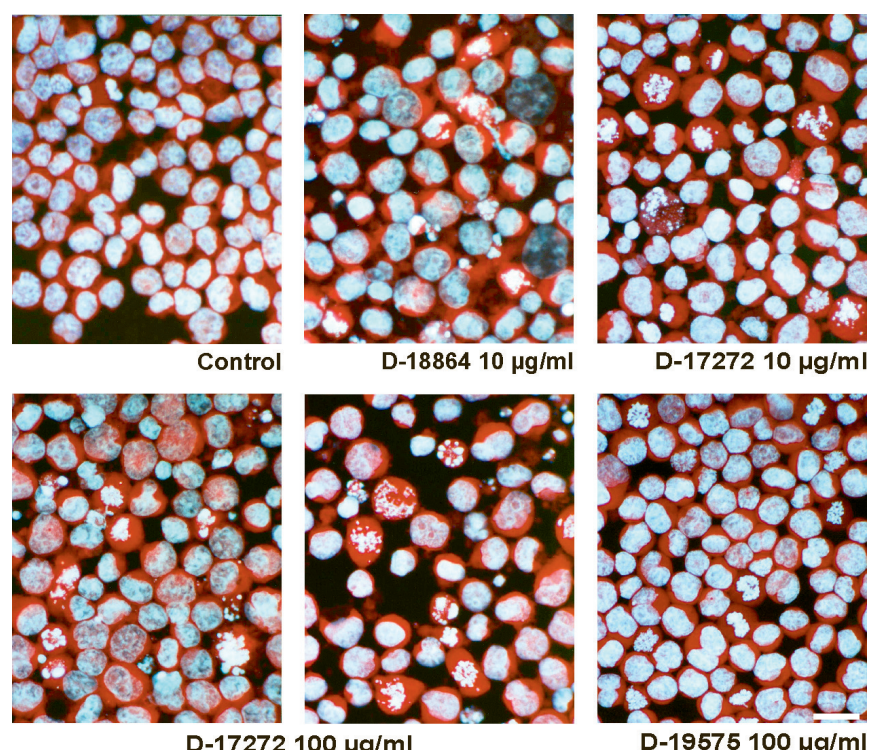

Fig. 4. Effects of oxazaphosphorines on human promyelocytic leukemia HL-60 cells. Morphology of HL-60 cells observed 72h after their exposure to the action of the three oxazaphosphorine agents D-18864, D-17272 and D-19575. The leukemic HL-60 cells, stained with the DNA specific fluorochrome DAPI and the protein fluorochrome sulforhodamine 101, are visible under a Zeiss fluorescence microscope. Hallmarks of mitotic catastrophe, apoptosis, and necrosis were given in the methodology section. Scale bar $-20 \mu \mathrm{m}$. 
mental groups and at all three time intervals, i.e. $24 \mathrm{~h}, 48 \mathrm{~h}$, and $72 \mathrm{~h}$ after exposure to oxazaphosphorines. Among the oxazaphosphorine tested, the smallest mean volume of HL-60 cells was observed when D-19575 was applied at a dose of 100 $\mu \mathrm{g} / \mathrm{ml}$ medium. Larger values of mean cell volume were found $48 \mathrm{~h}$ after D-18864 and D-17272 application, at a dose of $10 \mu \mathrm{g} / \mathrm{ml}$ medium, and $72 \mathrm{~h}$ after leukemic cell exposure to D-17272 at a dose of 100 $\mu \mathrm{g} / \mathrm{ml}$ medium, compared to values obtained at the remaining time intervals (Table 2).

Table 2

The mean volume of HL-60 cells after their exposure to oxazaphosphorine agents

\begin{tabular}{|c|c|c|c|c|c|}
\hline \multirow{2}{*}{\multicolumn{3}{|c|}{ Group characteristic }} & \multicolumn{3}{|c|}{ Time intervals after cell exposure to oxazaphosphorines } \\
\hline & & & $24 \mathrm{~h}$ & $48 \mathrm{~h}$ & $72 \mathrm{~h}$ \\
\hline \multirow{2}{*}{ No. } & \multirow{2}{*}{ Agent given } & \multirow{2}{*}{ Agent dose } & \multicolumn{3}{|c|}{ Mean Cell Volume (fL) } \\
\hline & & & Mean \pm SD & Mean \pm SD & Mean \pm SD \\
\hline I & D-18864 & $10 \mu \mathrm{g} / \mathrm{ml}$ & $\begin{array}{c}2,3,4,5,48 \mathrm{~h}, 72 \mathrm{~h} \\
3246 \pm 73\end{array}$ & $\begin{array}{c}2,3,4,5,24 \mathrm{~h}, 72 \mathrm{~h} \\
4594 \pm 80\end{array}$ & $\begin{array}{c}2,3,4,5,24 \mathrm{~h}, 48 \mathrm{~h} \\
3842 \pm 36\end{array}$ \\
\hline II & D-17272 & $10 \mu \mathrm{g} / \mathrm{ml}$ & $\begin{array}{c}1,3,4,5,48 \mathrm{~h} \\
3534 \pm 49\end{array}$ & $\begin{array}{c}1,3,4,5,24 \mathrm{~h}, 72 \mathrm{~h} \\
4473 \pm 63\end{array}$ & $\begin{array}{c}1,3,4,5,48 \mathrm{~h} \\
3557 \pm 88\end{array}$ \\
\hline III & D-17272 & $100 \mu \mathrm{g} / \mathrm{ml}$ & $\begin{array}{c}1,2,4,5,48 \mathrm{~h}, 72 \mathrm{~h} \\
2882 \pm 28\end{array}$ & $\begin{array}{c}1,2,4,5,24 \mathrm{~h}, 72 \mathrm{~h} \\
3923 \pm 90\end{array}$ & $\begin{array}{c}1,2,4,5,24 \mathrm{~h}, 48 \mathrm{~h} \\
4381 \pm 87\end{array}$ \\
\hline IV & D-19575 & $100 \mu \mathrm{g} / \mathrm{ml}$ & $\begin{array}{c}1,2,3,5,48 \mathrm{~h}, 72 \mathrm{~h} \\
2629 \pm 28\end{array}$ & $\begin{array}{c}1,2,3,5,24 \mathrm{~h}, 72 \mathrm{~h} \\
2789 \pm 27\end{array}$ & $\begin{array}{c}1,2,3,5,24 \mathrm{~h}, 48 \mathrm{~h} \\
2333 \pm 28\end{array}$ \\
\hline $\mathrm{V}$ & \multicolumn{2}{|c|}{ Control } & $\begin{array}{c}1,2,3,4,48 \mathrm{~h}, 72 \mathrm{~h} \\
2106 \pm 26\end{array}$ & $\begin{array}{c}1,2,3,4,24 \mathrm{~h}, 72 \mathrm{~h} \\
2227 \pm 15\end{array}$ & $\begin{array}{c}1,2,3,4,24 \mathrm{~h}, 48 \mathrm{~h} \\
1933 \pm 22\end{array}$ \\
\hline
\end{tabular}

For explanation of signs see Table 1.

Table 3

The count of HL-60 cells after their exposure to oxazaphosphorine agents

\begin{tabular}{|c|c|c|c|c|c|}
\hline \multirow{2}{*}{\multicolumn{3}{|c|}{ Group characteristic }} & \multicolumn{3}{|c|}{ Time intervals after cell exposure to oxazaphosphorines } \\
\hline & & & $24 \mathrm{~h}$ & $48 \mathrm{~h}$ & $72 \mathrm{~h}$ \\
\hline \multirow{2}{*}{ No. } & \multirow{2}{*}{ Agent given } & \multirow{2}{*}{ Agent dose } & \multicolumn{3}{|c|}{ Cell count $\left(\times 10^{3}\right)$} \\
\hline & & & Mean \pm SD & Mean \pm SD & Mean \pm SD \\
\hline I & D-18864 & $10 \mu \mathrm{g} / \mathrm{ml}$ & $\begin{array}{c}2,4,5,48 \mathrm{~h}, 72 \mathrm{~h} \\
167.99 \pm 9.31\end{array}$ & $\begin{array}{c}2,4,5,24 \mathrm{~h}, 72 \mathrm{~h} \\
150.42 \pm 6.26\end{array}$ & $\begin{array}{c}2,4,5,24 \mathrm{~h}, 48 \mathrm{~h} \\
96.50 \pm 4.13\end{array}$ \\
\hline II & D-17272 & $10 \mu \mathrm{g} / \mathrm{ml}$ & $\begin{array}{l}1,3,4,5,72 \mathrm{~h} \\
194.23 \pm 5.20\end{array}$ & $\begin{array}{l}1,3,4,5,72 \mathrm{~h} \\
208.37 \pm 10.91\end{array}$ & $\begin{array}{c}1,3,4,5,24 \mathrm{~h}, 48 \mathrm{~h} \\
432.26 \pm 8.20\end{array}$ \\
\hline III & D-17272 & $100 \mu \mathrm{g} / \mathrm{ml}$ & $\begin{array}{c}2,4,5,72 \mathrm{~h} \\
158.33 \pm 6.85\end{array}$ & $\begin{array}{c}2,4,5,72 \mathrm{~h} \\
151.00 \pm 7.97\end{array}$ & $\begin{array}{c}2,4,5,24 \mathrm{~h}, 48 \mathrm{~h} \\
102.68 \pm 7.09\end{array}$ \\
\hline IV & D-19575 & $100 \mu \mathrm{g} / \mathrm{ml}$ & $\begin{array}{c}1,2,3,5,48 \mathrm{~h}, 72 \mathrm{~h} \\
278.73 \pm 10.92\end{array}$ & $\begin{array}{c}1,2,3,5,24 \mathrm{~h}, 72 \mathrm{~h} \\
637.00 \pm 20.97\end{array}$ & $\begin{array}{c}1,2,3,5,24 \mathrm{~h}, 48 \mathrm{~h} \\
1036.55 \pm 16.58\end{array}$ \\
\hline $\mathrm{V}$ & \multicolumn{2}{|c|}{ Control } & $\begin{array}{c}1,2,3,4,48 \mathrm{~h}, 72 \mathrm{~h} \\
345.95 \pm 22.07\end{array}$ & $\begin{array}{c}1,2,3,4,24 \mathrm{~h}, 72 \mathrm{~h} \\
846.75 \pm 17.72\end{array}$ & $\begin{array}{c}1,2,3,4,24 \mathrm{~h}, 48 \mathrm{~h} \\
1315.65 \pm 35.01\end{array}$ \\
\hline
\end{tabular}

For explanation of signs see Table 1. 
Table 4

The frequency of HL-60 cells undergoing mitotic catastrophe after oxazaphosphorine application

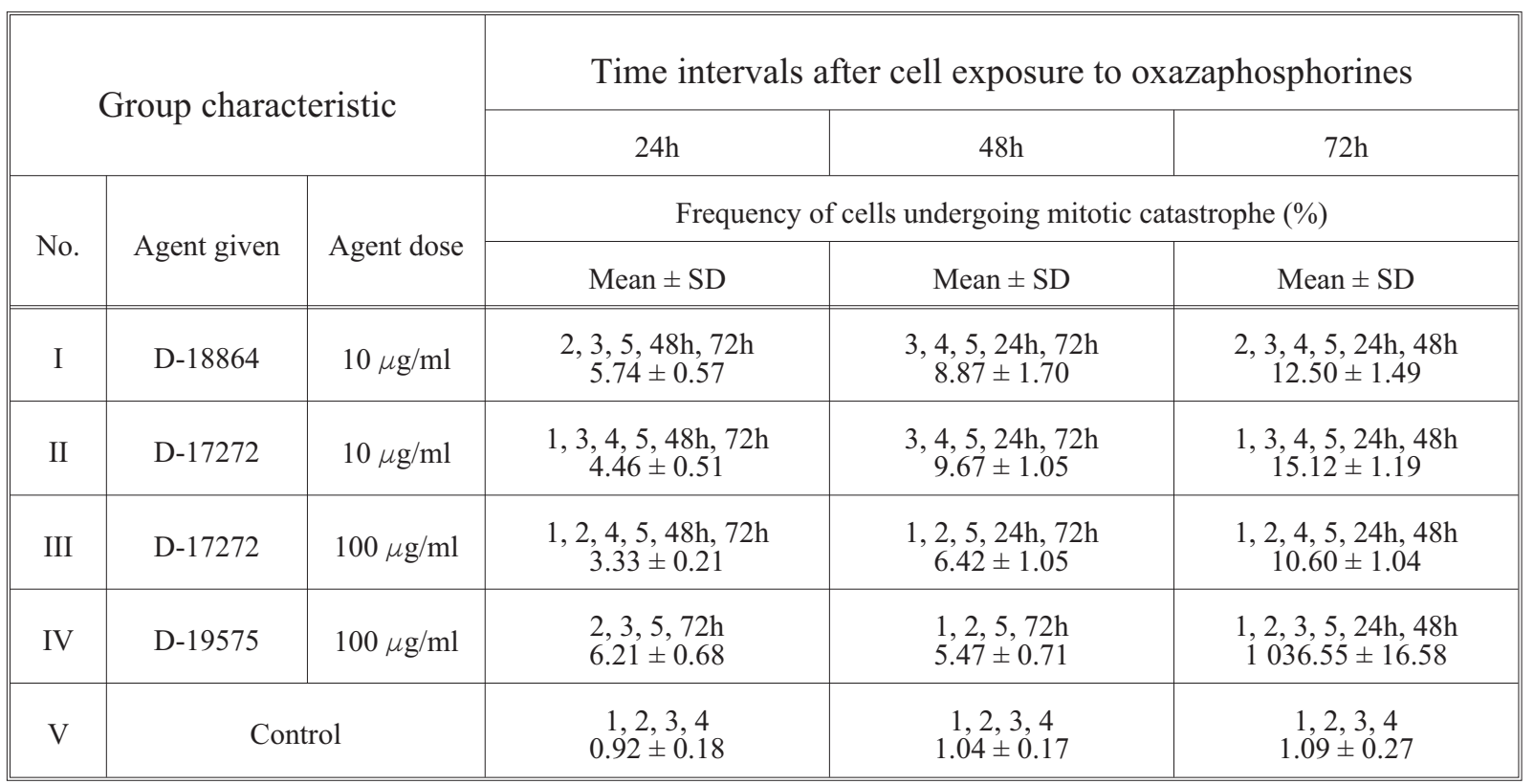

For explanation of signs see Table 1.

\section{Cell count}

In comparison with the controls, the cell count of HL-60 cells decreased in all the remaining experimental groups and at all time intervals $(24,48 \mathrm{~h}$, and $72 \mathrm{~h}$ ) after oxazaphosphorine application. Among HL-60 cells, the highest cell number was encountered when D-19575 was given at a dose of $100 \mu \mathrm{g} / \mathrm{ml}$ medium. After the treatment of HL-60 cells with D-17272 at two doses of $10 \mu \mathrm{g} / \mathrm{ml}$ and $100 \mu \mathrm{g} / \mathrm{ml}$ medium, the cell count appeared to be reduced in a dose-dependent manner. D-18864 given at a dose of $10 \mu \mathrm{g} / \mathrm{ml}$ caused a greater decrease of the leukemic cell number than D-17272 applied at the same dose (Table 3).

\section{Mitotic catastrophe}

In comparison with the controls, the yield of mitotic catastrophe increased in all the remaining experimental groups and at all three time intervals (24h, 48h, and 72h) after HL-60 cell exposure to the tested oxazaphosphorines. The frequency of the leukemic cells undergoing mitotic catastrophe increased over time after application of D-18864 and D-17272, and decreased over time when D-19575 was given. The highest yield of mitotic catastrophe was observed $72 \mathrm{~h}$ after the treatment of HL-60 cells with D-17272 at a dose of $10 \mu \mathrm{g} / \mathrm{ml}$ medium (Table 4).

\section{Apoptosis}

In relation to the controls, the frequency of apoptotic HL-60 cells increased in all the remaining experimental groups and at all three time intervals (24h, 48h, and $72 \mathrm{~h}$ ) after leukemic cell exposure to the oxazaphosphorine agents. Among the oxazaphosphorines tested, the lowest frequency of HL-60 cells undergoing apoptosis was found when D-19575 was applied. The effects of D-17272 on apoptosis-induction in HL-60 cells was dose-dependent. The frequency of apoptotic cells was lower after D-17272 application at a dose of $10 \mu \mathrm{g} / \mathrm{ml}$ medium than when D-18864 was given at the same dose (Table 5).

\section{Necrosis}

In comparison with the controls, a higher frequency of HL-60 cells undergoing necrosis was found in all the remaining experimental groups and at all three time intervals (24h, $48 \mathrm{~h}$, and $72 \mathrm{~h}$ ) after the application of oxazaphosphorine. Among the tested oxazaphosphorines, the lowest frequency of necrotic cells was found after exposure of HL-60 cells to the action of D-19575. After treatment of the leukemic cells with D-17272 at two doses of $10 \mu \mathrm{g} / \mathrm{ml}$ and $100 \mu \mathrm{g} / \mathrm{ml}$ medium, the yield of necrosis increased in a dose-dependent 
Table 5

The frequency of HL-60 cells undergoing apoptosis after oxazaphosphorine application

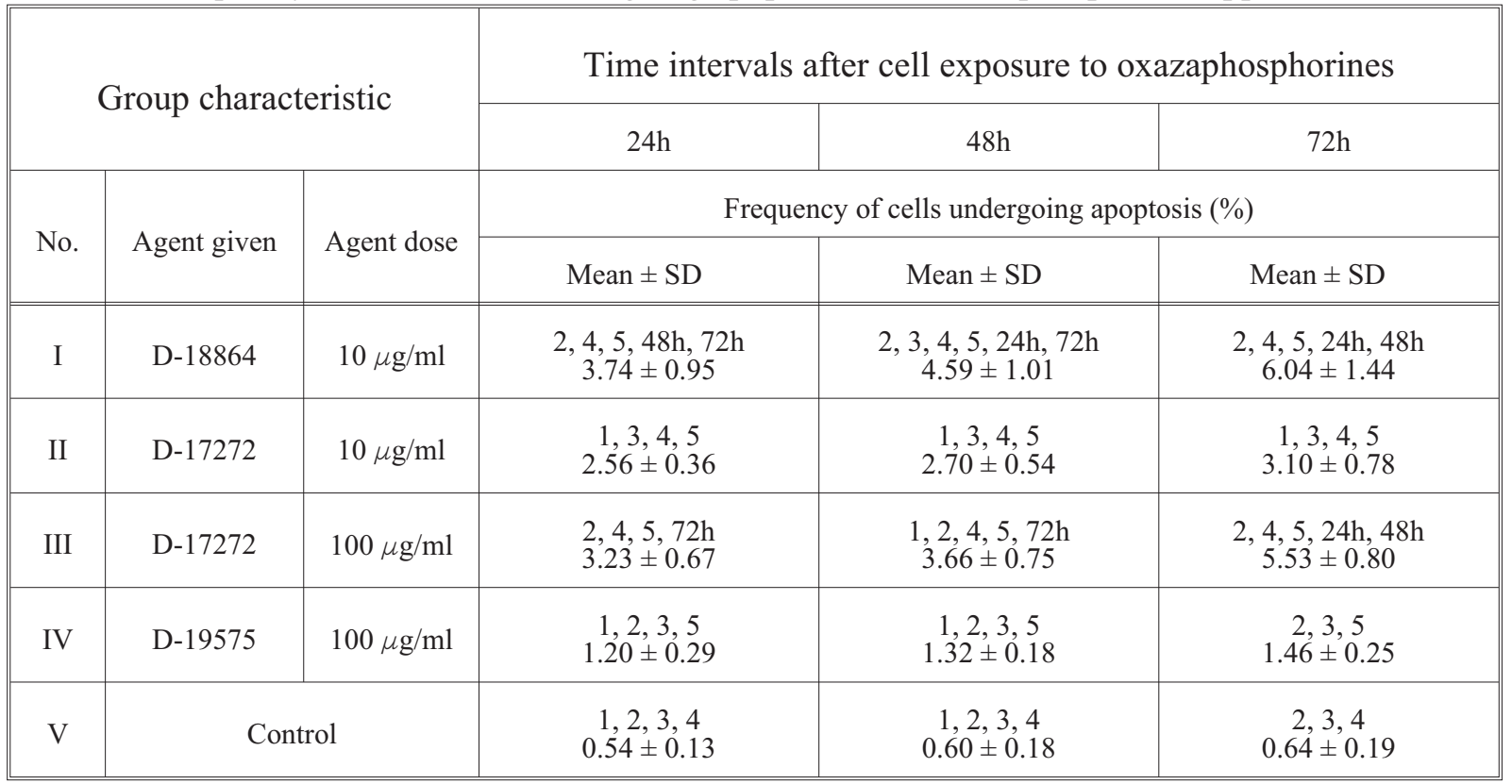

For explanation of signs see Table 1.

Table 6

The frequency of HL-60 cells undergoing necrosis after oxazaphosphorine application

\begin{tabular}{|c|c|c|c|c|c|}
\hline \multirow{2}{*}{\multicolumn{3}{|c|}{ Group characteristic }} & \multicolumn{3}{|c|}{ Time intervals after cell exposure to oxazaphosphorines } \\
\hline & & & $24 \mathrm{~h}$ & $48 \mathrm{~h}$ & $72 \mathrm{~h}$ \\
\hline \multirow{2}{*}{ No. } & \multirow{2}{*}{ Agent given } & \multirow{2}{*}{ Agent dose } & \multicolumn{3}{|c|}{ Frequency of cells undergoing necrosis (\%) } \\
\hline & & & Mean $\pm \mathrm{SD}$ & Mean $\pm \mathrm{SD}$ & Mean $\pm \mathrm{SD}$ \\
\hline I & D-18864 & $10 \mu \mathrm{g} / \mathrm{ml}$ & $\begin{array}{l}2,4,5,48 \mathrm{~h}, 72 \mathrm{~h} \\
5.31 \pm 1.18\end{array}$ & $\begin{array}{c}2,3,4,5,24 \mathrm{~h} \\
6.74 \pm 1.25\end{array}$ & $\begin{array}{c}2,3,4,5,24 \mathrm{~h} \\
7.57 \pm 1.04\end{array}$ \\
\hline II & D-17272 & $10 \mu \mathrm{g} / \mathrm{ml}$ & $\begin{array}{l}1,4,5,72 \mathrm{~h} \\
4.08 \pm 0.32\end{array}$ & $\begin{array}{c}1,3,5 \\
4.33 \pm 1.26\end{array}$ & $\begin{array}{l}1,3,5,24 \mathrm{~h} \\
5.18 \pm 1.29\end{array}$ \\
\hline III & D-17272 & $100 \mu \mathrm{g} / \mathrm{ml}$ & $\begin{array}{c}4,5,72 \mathrm{~h} \\
4.63 \pm 1.03\end{array}$ & $\begin{array}{c}1,5,72 \mathrm{~h} \\
4.62 \pm 0.95\end{array}$ & $\begin{array}{l}1,2,4,5,24 \mathrm{~h}, 48 \mathrm{~h} \\
\quad 6.21 \pm 1.21\end{array}$ \\
\hline IV & D-19575 & $100 \mu \mathrm{g} / \mathrm{ml}$ & $\begin{array}{c}1,2,3,5,48 \mathrm{~h}, 72 \mathrm{~h} \\
2.31 \pm 0.36\end{array}$ & $\begin{array}{c}1,5,24 \mathrm{~h} \\
3.97 \pm 0.85\end{array}$ & $\begin{array}{l}1,3,5,24 \mathrm{~h} \\
4.28 \pm 0.95\end{array}$ \\
\hline $\mathrm{V}$ & \multicolumn{2}{|c|}{ Control } & $\begin{array}{c}1,2,3,4 \\
0.87 \pm 0.21\end{array}$ & $\begin{array}{c}1,2,3,4 \\
0.91 \pm 0.24\end{array}$ & $\begin{array}{c}1,2,3,4 \\
1.01 \pm 0.20\end{array}$ \\
\hline
\end{tabular}

For explanation of signs see Table 1.

manner. Necrotic death was induced in HL-60 cells to a greater degree when D-18864 was given at a dose of $10 \mu \mathrm{g} / \mathrm{ml}$ than when D-17272 was applied at the same dose (Table 6).

\section{Discussion}

In the present study, the activity of the new generation oxazaphosphorines, D-17272, D-18864 and D-19575, against human promyelocytic leu- 
kemia HL-60 cells was evaluated. Various patterns of temporary changes in cell viability, size and count, and in the frequency of cells undergoing mitotic catastrophe and programmed cell death, were found at $24 \mathrm{~h}, 48 \mathrm{~h}$ and $72 \mathrm{~h}$ after exposure of HL-60 cells to the action of these three oxazaphosphorine agents. The results obtained in the present investigation and previous studies point to the varied action of D-18864, D-17272, and D-19575 on pathological hematopoietic cells. The damage caused by these alkylating agents in HL-60 cells was manifested as decreased cell viability, different cell volume distribution, reduced cell count, induction of mitotic catastrophe, and triggering apoptotic and necrotic cell death. The decreased viability rate and a reduced count of MOLT-4 cells and ML-1 cells treated with oxazaphosphorines were also observed by OPYDOCHANEK et al. (2011) and MAZUR et al. (2012b). The effects of D-18864, D-17272 and D-19575 on mitotic catastrophe-induction in U937 cells was demonstrated by MAZUR et al. (2009). The influence of the cyclophosphamide analogue mafosfamide on triggering apoptotic death in human lymphoblastoid cells was reported by GOLDSTEIN et al. (2008). The size distribution of MOLT-4 cells, U-937 cells and ML-1 cells exposed to oxazaphosphorines was shown by OPYDO-CHANEK et al. $(2010,2011)$ and MAZUR et al. (2012b). The human leukemic cell response to the action of D-17272, D-18864 and D-19575 found in the previous and present investigations appeared to be dependent on the agent tested and its dose, the time intervals after oxazaphosphorine application and the cell line used (MAZUR et al. 2009, 2010, 2012b; OPYDO-CHANEK et al. 2010, 2011).

The alterations observed in the leukemic cells following their exposure to D-18864, D-17272 and D-19575 surely resulted from abnormal processes occurring at the molecular, biochemical, and cellular levels. The exact mechanisms of action of the three oxazaphosphorine agents are almost entirely unknown (BODY \& YULE 2000; ZHANG et al. 2005b; LIANG et al. 2007). What is known is that D-18864, 4-hydro-peroxy-cyclophosphamide generates its active principle 4-hydroxycyclophosphamide (4-OH-CP). D-17272, a mafosfamide cyclohexylamine salt, generates $4-\mathrm{OH}-\mathrm{CP}$. Phosphoramide mustard and acrolein are the major reactive alkylating agents of the two prodrugs D-18864 and D-17272. $\beta$-D-glucose-isophosphoramide mustard, D-19575, contains the directly reactive alkylating moiety, isophosphoramide mustard. These reactive alkylating agents are responsible for the cytotoxicity of oxazaphosphorines. The anticancer activity of D-18864, D-17272 and D-19575 is believed to also be dependent on the pharmacokinetic and pharmacody- namic properties of these alkylating agents due to their different chemical structure (BODY \& YULE 2000; ENGEL et al. 2000; SEKER et al. 2000; ZHANG et al., 2005a, 2005b; LIANG et al. 2007; MAZUR et al. 2011, 2012a).

In summary, the results of the present study are the first data comparing the potential of the three oxazaphosphorines, D-17272, D-18864, and D-19575, to induce mitotic catastrophe and programmed death, and affect the viability, size and count of human promyelocytic leukemia HL-60 cells. An elucidation of the mechanisms responsible for the various activities of the new generation oxazaphosphorine agents against the different types of pathological hematopoietic cells can provide the rationale for their optional use in chemotherapy.

\section{Acknowledgements}

The authors wish to thank Urszula KŁAPUT for her excellent technical assistance.

\section{References}

BECKER R., RitTER A., EICHHORN U., LIPS S. J., BERTRAM B., WIESSLER M., ZDZIENICKA A. M. Z., KAINA B. 2002. Induction of DNA breaks and apoptosis in crosslink hypersensitive V79 cells by cytostatic drug beta-D-glucosyl-ifosfamide mustard. Br. J. Cancer 86: 130-135.

Body A. V., YulE S. M. 2000. Metabolism and pharmacokinetics of oxazaphosphorines. Clin. Pharmacokinet. 38: 291-304.

Borst, P., RotTenBerg S. 2004. Cancer cell death by programmed necrosis ? Drug Resist. Update. 7: 321-324.

DE BRuin E. C., Medema J. P. 2008. Apoptosis and nonapoptotic deaths in cancer development and treatment response. Cancer Treat. Rev. 34: 737-749.

Engel J., Klenner T., Niemeyer U., Peter G., POHL J., SCHÜleR M., SCHUPKe E. A., VosS A., WeISSLER M. 2000. Glufosfamide. Drug. Future 25: 791-794.

Giraud B., Hebert G., Deroussent A., Veal G. L., VASSAL G., PACI A. 2010. Oxazaphosphorines: new therapeutic strategies for an old class of drugs. Expert Opin. Drug Metab. Toxicol. 6: 919-938.

Goldstein M., Roos W. P., KainA B. 2008. Apoptotic death induced by the cyclophosphamide analogue mafosfamide in human lymphoblastoid cells: Contribution of DNA replication, transcription inhibition and Chk/p53 signaling. Toxicol. Appl. Pharmacol. 229: 20-32.

HendRiquez M., ARMisen R., STUtZin A., Quest A. F. G. 2008. Cell death by necrosis, a regulated way to go. Curr. Mol. Med. 8: 187-206.

JaCob E., SCorsone K., Blaney S. M., D'ARgenio D. Z., BERG S. L. 2008. Synergy of karenitecin and mafosfamide in pediatric leukemia, medulloblastoma, and neuroblastoma cell lines. Pediatr. Blood Cancer 50: 757-760.

Kaspers G.J. L., Veerman A. J. P., Pieters R., VAN ZANTWIJK I., HÄHLEN K., VAN WERING E. R. 1995. Drug combination testing in acute lymphoblastic leukemia using the MTT-assay. Leukemia Res. 19: 175-181.

KAUFMANN S. H., EARNSHAW W. C. 2000. Induction of apoptosis by cancer chemotherapy. Exp. Cell Res. 256: 42-49. 
Liang J., Huang M., Duan W., Yu X. O., Zhou U. S. 2007. Design of new oxazaphosphorine anticancer drugs. Curr. Pharm. Des. 13: 963-978.

MAKIN G., HICKMAN J. A. 2000. Apoptosis and cancer chemotherapy. Cell Tissue Res. 301: 143-152.

Mansilla S., Bataller M., Portugal J. 2006. Mitotic catastrophe as a consequence of chemotherapy. Anti-Cancer Agent. Med. Chem. 6: 589-602.

MAZUR L., OPYDO-CHANEK M. STOJAK M. 2011. Glufosfamide as a new oxazaphosphorine anticancer agent. AntiCancer Drug. 22: 488-493.

MaZur L., Opydo-ChaneK, M., STOJaK M., Baran J., NIEMEYER U. 2010. Induction of DNA breakage in U937 cells by oxazaphosphorines. Folia Biol. (Kraków) 58: 15-20

MAZUR L., OPyDO-CHANEK M., STOJAK M., WOJCIESZEK K 2012a. Mafosfamide as a new anticancer agent: Preclinica investigations and clinical trials. Anticancer Res. 32 2783-2790.

MAZUR L., OPYDO-CHANEK M., WOJCIESZEK K., STOJAK M., NIEMEYER U. 2012b. Comparative effects of new generation oxazaphosphorines on the size and viability of human acute myeloblastic leukemia cells. Folia Biol. (Kraków) 60 $35-40$.

MAZUR L., StojaK M., Opydo-ChaneK M., NiEMEyer U. 2009. Mitotic catastrophe induction in U937 cells by oxazaphosphorines. Acta Biol. Cracov. Ser. Zool. 51: 17-22.

OPYDO-CHANEK M., MAZUR L., STOJAK M., WOJCIESZEK K., NIEMEYER U. 2011. Cytotoxic effects of new generation oxazaphosphorines on human acute lymphoblastic leukemia cells. Acta Biol. Cracov. Ser. Zool. 53: 39-45.

Opydo-ChaneK M. Stojak M., MaZUR L., Niemeyer U. 2010. Changes in the size of U937 cells following exposure to new generation oxazaphosphorines. Acta Biol. Cracov. Ser. Zool. 52: 25-29.

PROSKURYAKOV S. Y., GABAI V. L., KONOPL YANNIKOV A. G. 2002. Necrosis is an active and controlled form of programmed cell death. Biochemistry (Moscow) 67: 467-491.
RAFFRAY M., COHEN G. M. 1997. Apoptosis and necrosis in toxicology: A continuum or distinct modes of cell death? Pharmacol. Ther. 75: 153-172.

RICCI M. S., ZONG W. X. 2006. Chemotherapeutic approaches for targeting cell death pathways. The Oncologist 11: $342-357$

Ross D. W. 1976. Cell volume growth after cell cycle block with chemotherapeutic agents. Cell Tissue Kinet. 9: 379-387.

Ross D. W. 1981a. The nature of unbalanced cell growth caused by cytotoxic agents. Virchows Archiv. B Cell Pathol. Zell-Pathol. 37: 225-235.

Ross D. W. 1981b. Volume increase in L5222 leukaemic cells following chemotherapy: Manifestation of leukaemic cell damage. Leukemia Res. 5: 73-80.

SeKer H., Bertram B., Burkle A., Kaina B., Pohl J., KOEPSELL H., WIESSLER M. 2000. Mechanistic aspects of the cytotoxic activity of glufosfamide, a new tumor therapeutic agent. Br. J. Cancer 82: 629-634.

STYCZYŃSKI J., WYSOCKI M., DĘBSKI R., BALWIERZ W., ROKICKA-MiLEWSKA R., MATYSIAK M., BALCERSKA A., KOWALCZYK J., WACHOWIAK J., SOŃTA-JAKIMCZYK D., CHYBICKA A. 2002a. In vitro activity of oxazaphosphorines in childhood acute leukemia: Preliminary repot. Acta Biochim. Pol. 49: 221-225.

STYCZYŃSKI J., WYSOCKI M., KURYLAK A., JURASZEWSKA E., MALINOWSKA I., STAŃCZAK E., PŁOSZYŃSKA A., STEFANIAK J., MAZUR B., SZCZEPAŃSKI T., RAS M. 2000b. In vitro activity of glufosfamide in childhood acute leukemia. Anticancer Res. 22: 247-250.

SUN Y., PENG Z. L. 2009. Programmed cell death and cancer. Postgrad. Med. J. 85: 134-140.

ZHANG J., Tian Q., CHAN S. Y., DuAN W., ZHOU S. 2005a. Insight into oxazaphosphorine resistance and possible approaches to its circumvention. Drug Resist. Uptake 8: 271-297.

Zhang J., Tian Q., Chan S. Y., Li S. C., ZHOU S. 2005b. Metabolism and transport of oxazaphosphorines and the clinical implications. Drug Metab. Rev. 37: 611-703. 